\title{
Fleksibilitas interpretatif teknologi web 2.0 bagi pengelola media sosial instansi pemerintah
}

\author{
Kunti Puspitasari ${ }^{1}$, Irwansyah ${ }^{2}$ \\ ${ }^{1,2}$ Universitas Indonesia, Jakarta, Indonesia
}

\begin{abstract}
ABSTRAK
Teknologi Web 2.0 sebagai web partisipatif ditandai kehadiran media sosial yang memiliki jangkauan luas dan cepat, serta melibatkan penggunanya. Saat ini, media sosial dimanfaatkan untuk menjalankan komunikasi publik kementerian/lembaga pemerintah. Media sosial instansi pemerintah seharusnya menawarkan interaksi antara instansi pemerintah dengan masyarakat sesuai tipologi Web 2.0 dan sebagai ruang layanan publik. Pengelolaan media sosial juga strategis dalam menjaga reputasi instansi pemerintah. Pengelolaan media sosial di kementerian/lembaga pemerintah umumnya dijalankan oleh kehumasan dengan menunjuk tim atau seorang pengelola/admin media sosial. Penelitian ini melihat bagaimana pengelola/admin media sosial kementerian/lembaga pemerintah sebagai kelompok sosial relevan (pengguna) menginterpretasikan teknologi Web 2.0, dalam hal ini media sosial, berdasarkan perspektif Social Construction of Technology (SCOT). Penelitian ini menggunakan pendekatan kualitatif dengan paradigma konstruksionisme. Metode pengumpulan data dengan wawancara mendalam kepada tiga pengelola/admin media sosial di tiga kementerian dan lembaga yang berbeda. Hasil penelitian menggambarkan pengelola/admin media sosial kementerian/lembaga pemerintah memiliki fleksibilitas interpretatif yang sama dalam menggunakan media sosial, namun berbeda dari cara kerjanya. Interpretasi ini terkait penggunaan ruang interaksi dalam merespon komentar warganet. Perbedaan cara penggunaan terkait dengan konteks yang lebih luas, yaitu kultur organisasi, pemahaman akan struktur lain, serta kondisi politik yang sedang berkembang. Penelitian ini memberikan rekomendasi bagi pengembangan konsep SCOT pada penggunaan media sosial kementerian/lembaga pemerintah bagi kelompok sosial relevan lainnya, yaitu pengamat.
\end{abstract}

Kata-kata Kunci: Humas pemerintah; konstruksi sosial; media sosial; situs; teknologi

\section{Interpretative flexibility of web 2.0 for social media admin}

\section{of government institutions}

\section{ABSTRACT}

Web 2.0 as a participatory web is characterized by social media with a broad and fast reach, offering user engagement throughout various apps. At present, government public relations use social media for public communication, providing interaction between these institutions and the community according to Web 2.0 typology and as a public service space. Social media management is also strategic in maintaining the reputation of government institutions. Social media management in government institutions is generally run by a public relations division, appointing a team or person as the social media administrators. This study looks at how social media administrators of government institutions as relevant social groups (users) interpret technology Web 2.0 according to Social Construction of Technology (SCOT). This study uses a qualitative approach with a constructionism paradigm. Data collection methods used are in-depth interviews with three social media admins in three different ministries and institutions. The results illustrate that social media admins at government institutions have the same interpretative flexibility in using social media but differ in implementation. This interpretation is related to interaction space by responding to netizens' comments. The differentways of use are related to the broader context, namelyorganizational culture, the understanding of other structures, and the developing political conditions. This study provides recommendations for the development of SCOT on using social media by government institutions for other relevant social groups, namely observers.

Keywords: Government public relations; social construction; social media; website; technology

Korespondensi: Kunti Puspitasari, S.Sos, Universitas Indonesia, Gedung IASTH Lantai 6 Kampus Universitas Indonesia Salemba, Jakarta Pusat, 10430,email: puspitakunti@gmail.com 


\section{PENDAHULUAN}

Kehadiran World Wide Web (Web) pada tahun 1989 bertujuan mengakses data dari mana saja kapan saja dalam bentuk bahasa hiperteks yang saling terkait (Patel, 2013). Web menjadi sistem sosio-teknis, yaitu sistem yang meningkatkan persepsi manusia, verbalisasi, afiliasi, dan integrasi untuk interaksi antara manusia dengan manusia melalui jaringan teknologi (Patel, 2013). Web generasi pertama (Web 1.0) terus mengalami perkembangan menjadi Web 2.0, Web 3.0, Web 4.0, hingga Web 5.0.

Perkembangan web tidak menyiratkan urutan temporal (seperti dalam versi perangkat lunak) atau seperti proses evolusi. Perbedaan di antara teknologi web menunjukkan semua aplikasi dan proses web saling bekerja sama, tidak saling menggantikan. Teknologi web terbaru juga mencakup aspek-aspek dalam teknologi web sebelumnya (Fuchs et al., 2010). Teknologi web memungkinkan berbagai proses komunikasi, yaitu kognisi, partisipasi, dan kerja sama (Barassi \& Treré, 2012). Masing-masing teknologi web memiliki tipologinya tersendiri dan kehadiran teknologi tersebut memberikan dampak bagi kehidupan masyarakat. Kemunculan Web 2.0 berbeda dari Web 1.0 yang menekankan pada proses kognitif manusia. Teknologi Web 2.0 memungkinkan penggunanya untuk mengelola dan mengumpulkan khalayak yang besar dengan minat bersama dalam interaksi sosial. Web 2.0 dikenal sebagai web partisipatif, di mana orang dapat membaca dan menulis informasi untuk dibagikan, atau bersifat interaktif dua arah. Web 2.0 mencakup jejaring sosial seperti MySpace, Facebook, Twitter; platform berbagi media seperti YouTube, Slideshare, dan Flicker; pengetahuan kolaboratif melalui wiki yaitu Wikipedia; konten kreatif seperti podcast, videocast, blog, dan microblog; agregasi dan organisasi konten; atau Really Simple Syndication (RSS) (Patel, 2013).

Teknologi web memudahkan penggunanya untuk berbagi informasi dengan jejaring sosialnya tanpa bertemu muka, serta menambah jejaring sosial baru yang memiliki minat yang sama. Perubahan web berdampak pada organisasi ekonomi dan politik masyarakat, serta pada sikap, kepercayaan, dan praktik di masyarakat. Web 2.0 menandai momen budaya yang lebih luas (Barassi \& Treré, 2012). Apalagi dengan kelahiran media sosial yang didefinisikan sebagai kelompok teknologi Web 2.0 yang memfasilitasi interaksi antara pengguna (Song \& Lee, 2016). Media sosial adalah platform berbasis internet yang memungkinkan para penggunanya untuk membuat dan berbagi konten (berisi informasi, opini, dan minat) dalam konteks yang beragam (informatif, edukatif, 
sindiran, kritik, dan sebagainya) kepada khalayak yang lebih luas (Khan, 2017). Media sosial memungkinkan individu penggunanya terhubung dan bersosialisasi satu sama lain, menyebarkan informasi, serta mengekspresikan diri (Lin et al., 2014).

Media sosial dapat berupa blog, forum, atau Social Networking Sites (SNS). Media sosial mempunyai efek berantai sehingga proses transmisi yang terjadi tidak berhenti pada satu audiens pokok saja (multiplier effect). Media sosial menjadi media yang populer diakses karena kecepatannya dan jangkauannya yang luas, serta menawarkan keterlibatan penggunanya (engagement). Media sosial disebut sebagai consumer-generated media atau sebagai user-generated content (Wright \& Hinson, 2009). Hal ini karena media sosial memungkinkan penggunanya membuat konten sendiri dan menyebarkannya.

Media sosial yang mencakup berbagai platform online, seperti SNS, menjadi media komunikasi dari mulut ke mulut (word-ofmouth) yang kuat dan mengubah cara orang berkomunikasi. Kehadiran media sosial juga membuat penggunanya dapat berbagi informasi, terhubung dengan kelompok sosial mereka, dan menemukan teman baru (Petrescu \& Korgaonkar, 2011). Inilah yang menjadi kekuatan media sosial yang dimanfaatkan berbagai bidang.
Pemanfaatan media sosial, khususnya SNS, jamak dilakukan, seperti pada kampanye politik, penyampaian kebijakan publik, komunikasi pemasaran, serta hubungan masyarakat (humas). Teknologi Web 2.0 memungkinkan peningkatan aliran informasi pribadi di seluruh jaringan, munculnya alat yang kuat untuk pengawasan sejawat, eksploitasi tenaga kerja gratis untuk keuntungan komersial, serta peningkatan korporatisasi ruang dan output jaringan sosial online (Barassi \& Treré, 2012).

Di era media sosial, hampir semua kegiatan pemerintah sebenarnya terbuka untuk publik dan disampaikan melalui media sosial. Aspek pemerintahan digital ditunjukkan dengan penggunaan sumber daya online dalam mendukung kegiatan pemerintah, seperti membuat peraturan atau kebijakan publik, mendorong partisipasi warga, penyediaan referensi dan informasi kepada publik, serta dalam menyediakan pelayanan dan pengaduan masyarakat (Kartikawangi, 2020). Sebagian besar kementerian/lembaga di Indonesia saat ini telah memanfaatkan media sosial resminya sebagai platform untuk menjalankan komunikasi publik. Di era digital, komunikasi publik yang dijalankan humas pemerintah sudah seharusnya berlangsung secara dua arah (interaktif) dengan menggunakan media sosial. Humas pemerintah sebagai fasilitator komunikasi harus mengelola atau menciptakan komunikasi dua arah dengan 
publiknya. Hal ini dikarenakan fungsi humas pemerintah adalah sebagai jembatan antara publik dan lembaga (Prastowo, 2020).

Pemanfaatan media sosial dalam pemerintahan dapat meningkatkan persepsi warga terhadap transparansi pemerintah dengan memungkinkan mereka mengakses informasi pemerintah yang lebih mutakhir melalui interaksi yang lebih sering dengan pemerintah. Media sosial dalam pemerintahan dipahami membuat informasi pemerintah relatif lebih banyak dapat diakses oleh masyarakat (Song \& Lee, 2016).

Media sosial dalam pemerintahan memungkinkan masyarakat untuk mendapatkan akses lebih mudah ke pemerintah dan mendapat informasi lebih banyak tentang kejadian terkini, kebijakan, atau program, mempertinggi persepsi mereka tentang transparansi pemerintah. Media sosial memungkinkan masyarakat dan pemerintah berada di manamana, memungkinkan mereka lebih sering berinteraksi. Ketika masyarakat terhubung ke pemerintah melaluimedia sosial, merekaberpikir pemerintah adalah bagian dari komunitas online yang lebih besar, di mana masyarakat tidak hanya terhubung ke pemerintah, tetapi juga terikat dengan masyarakat lain yang tidak aktif menggunakan media sosial pemerintah (Changsoo, 2015). Media sosial dalam pemerintahan berfungsi sebagai sarana efektif untuk menyebarkan informasi tentang pemerintah, memberi warga peluang untuk mengakses informasi tentang pemerintah yang paling mutakhir secara tepat waktu. Masyarakat dapat merasa lebih terhubung dengan pejabat pemerintah. Perasaan terhubung tersebut dapat menunjukkan pemerintah dapat dipercaya (Song \& Lee, 2016). Dengan kata lain, tingkat kepercayaan masyarakat terhadap pemerintah dapat lebih meningkat.

Media sosial memiliki karakteristik yang unik, yaitu keterbukaan, partisipasi, dan berbagi. Karena popularitasnya dan karakteristiknya tersebut, media sosial menjadi perantara penting dalam interaksi antarpemerintah, pemerintah dan masyarakat, serta lembaga dan bisnis pemerintah (Criado et al., 2013). Saat ini muncul istilah Public Relations (PR) 2.0 yang mengacu pada penggunaan teknologi informasi dan komunikasi dalam pengelolaan kehumasan pemerintah. Dalam PR 2.0, humas harus menyadari bahwa mereka harus memenuhi kebutuhan pelanggan dengan berbagai cara. Hal ini karena pemangku kepentingan menginginkan perlakuan dan komunikasi yang unik dari hubungan publik yang terjalin. Inilah yang disebut sebagai one to one communication (Binsar \& Salamah, 2018). Humas pemerintah era digital tidak lagi dapat memakai cara-cara lama dalam menginformasikan program atau kebijakan. Penggunaan teknologi, khususnya 
media sosial, menjadi tuntutan humas pemerintah saat ini untuk memenuhi kebutuhan publik terhadap informasi terkini mengenai instansi pemerintah terkait.

Empat hal dalam pengelolaan media sosial di kementerian/lembaga pemerintah. Pertama, media sosial didesain untuk menjaga dan meningkatkan reputasi lembaga, serta menggali aspirasi publik. Kedua, media sosial sebagai media interaktif untuk lembaga sebaiknya dapat terhubung lebih dekat dengan publik. Ketiga, media sosial adalah dokumentasi online. Keempat, media sosial menjangkau publik yang sangat luas, sehingga diperlukan pemahaman dalam penyebaran informasi dan cara berkomunikasi lintas budaya (Kurniasih, 2016).

Pemanfaatan media sosialoleh kementerian/ lembaga pemerintah perlu memerhatikan karakteristik ruang media sosial yang ada dan yang diharapkan dari pengguna. Ruang media sosial memang dirancang melalui pengalaman strukturfisik, baik ruang obrolan, electronic gate, beranda, atau lalu lintas informasinya. Dimensi spasial menekankan pentingnya struktur dasar yang mendasarinya, yaitu sifat dan desainnya dalam membentuk aksi sosial secara online. Ruang virtual didasari oleh ruang jejaring sosial yang beragam, masing-masing dengan elemen budaya mereka sendiri. Ruang virtual menjadi terkait dengan pemenuhan diri individu dan pengembangan pribadi. Tipologi berbasis metafora untuk memahami dan mengatur budaya dominan ruang Web 2.0 yang dirancang dan didorong oleh niat tertentu dari aktor yang terlibat (Arora, 2012). Salah satu tipologi Web 2.0 adalah utilitarian-driven, di mana ruang media sosial dimetaforakan sebagai jalan raya. Dalam metafora ini, internet sebagian besar dipandang sebagai ruang utilitas (kegunaan). Hal ini dimaksudkan untuk kepastian tujuan dan niat yang terwujud melalui metafora harapan dan aspirasi. Sifat ruang online ini terletak pada dorongan kebutuhan akan fungsi atau manfaatnya dengan mengoptimalkan desain dan penggunaannya. Jenis ruang ini ditandai oleh implikasi praktis dalam bentuk layanan kepada masyarakat (Arora, 2012).

Dalam mengelola media sosial kementerian/ lembaga pemerintah, para pengelola/admin media sosial memiliki interpretasi mengenai teknologi yang digunakannya. Dalam hal ini, teknologi dan budaya saling berhubungan. Teknologi merupakan kekuatan pendorong untuk sosial dan perubahan budaya. Spigel membahas hubungan dialogis antara teknologi dan budaya, yaitu jalan masuk di mana teknologi memengaruhi cara kita berpikir tentang teknologi. Sementara cara kita berpikir tentang teknologi memengaruhi teknologi itu sendiri. Pinch dan Bijker mengemukakan Social Construction of Technology (SCOT) 
sebagai metode/pendekatan untuk memahami inovasi artefak teknologi tertentu. SCOT memperoleh momentum baru pada era Web 2.0, di mana teknologi Web 2.0 bersifat partisipatif, pengguna biasanya dilihat tidak hanya sebagai konsumen pasif tetapi juga sebagai prosumers dengan peran aktif dalam produksi konten media (Savic, 2021).

Pinch dan Bijker menguraikan empat komponen untuk SCOT, yaitu kelompok sosial yang relevan, fleksibilitas interpretatif, penutupan, dan stabilisasi (Humphreys, 2006).

Pinch dan Bijker juga mendeteksi adanya kontribusi situasi sosiokultur (sociocultural) dan politik di sekitar kelompok sosial dalam pembentukan norma dan nilai-nilai yang dianut oleh kelompok sosial tersebut. Norma dan nilai-nilai yang dianut suatu kelompok sosial akan memengaruhi makna yang diberikan oleh kelompok sosial itu terhadap artefak teknologi yang dihadapinya (Octavianto, 2014). Hal inilah yang termasuk ke dalam the wider context.

SCOT berpendapat teknologi dikembangkan melalui proses evolusi di mana sejumlah variasi dalam desain dibuat dan satu atau lebih banyak dipilih dan dipertahankan. Desain mana yang dipilih tergantung pada tidak hanya teknis kelayakan desain, tetapi juga pada kekuatan sosial dan ekonomi kelompok dengan minat pada artefak (Fulk \& Yuan, 2017). SCOT menyoroti bahwa teknologi diciptakan sebagai tanggapan terhadap konteks sosial dan budaya, namun teknologi juga tunduk pada negosiasi berkelanjutan di antara pencipta, pengguna, dan bukan pengguna atas tujuan dan desainnya (Savic, 2021).

Pinch dan Bijker mendefinisikan kelompok sosial yang relevan sebagai semua anggota suatu kelompok tertentu yang memiliki makna yang sama yang diberikan pada suatu artefak. Masing-masing kelompok membangun artefak dalam istilah mereka sendiri dan bergantung pada penggunaannya sendiri. Tidak semua kelompok sosial yang relevan memiliki kekuatan dan pengaruh yang sama atas teknologi. Penting untuk memahami tujuan serta sumber daya kelompok sosial yang terkait dengan artefak tertentu. Ada empat kategori umum kelompok sosial yang mencakup teknologi, yaitu producers (produsen), advocates (pendukung), users (pengguna), dan bystanders (pengamat). Masing-masing kelompok ditentukan oleh hubungan mereka dengan teknologi, baik langsung maupun tidak langsung, dan apakah mereka terorganisir jaringan atau individu yang memenuhi syarat (Humphreys, 2006).

Pengelola/admin media sosial kementerian/ lembaga pemerintah termasuk kelompok users (pengguna) media sosial karena berhubungan langsung dengan artefak teknologi tersebut. Admin media sosial menjadi perwakilan 
kementerian/lembaga pemerintah dalam berinteraksi dengan masyarakat menggunakan media sosial. Kelompok pengguna memiliki hubungan langsung dengan teknologi dan secara sosial membangun teknologi melalui penggunaannya atau potensi penggunaannya. Meskipun pengguna dapat mengidentifikasi atau bergabung dengan kelompok pengguna atau yang memiliki minat yang sama, mereka tidak secara aktif menegosiasikan makna artefak melalui kelompok-kelompok tersebut. Pengguna tidak hanya membantu membangun artefak dan maknanya secara sosial untuk mereka sendiri, tetapi dapat memengaruhi mereka di sekitarnya melalui tampilan publik dari penggunaan atau percakapan tentang artefak (Humphreys, 2006). Pengguna berkontribusi besar pada bagaimana orang lain menghargai dan memahami teknologi. Melalui konstruksi sosial, fungsi yang dibangun ke dalam teknologi yang relatif stabil melayani kepentingan beberapa elemen masyarakat di atas yang lain (Fulk \& Yuan, 2017).

Kementerian/lembaga merupakan organisasi publik yang bersifat birokratif. Hal tersebut menjadi kebaruan dalam penelitian ini yang ingin melihat interpretasi pengelola/ admin media sosial terhadap teknologi Web 2.0, dalam hal ini media sosial, dari perspektif SCOT dalam lingkungan birokrasi. Pengelolaan media sosial kementerian/lembaga pemerintah memiliki aturan tersendiri yang memengaruhi pada reputasi kementerian/lembaga. Pada tahun 2017, akun Twitter@setkabgoid (Sekretariat Kabinet RI) pernah salah kutip dalam menyampaikan pernyataan Joko Widodo (Jokowi) tentang organisasi yang memiliki aliran radikal dan intoleran. Karena kasus ini, admin Twitter dinonaktifkan (Mojo, 2018). Akun Twitter Presiden Jokowi juga pernah mengalami kekeliruan unggah pada tahun 2018. Admin Twitter akun Presiden Jokowi mencuit konten pribadi, menanggapi cuitan Beby JKT48 (personel grup musik di Indonesia). Cuitan ini menjadi viral, membuat admin Twitter Joko Widodo dibebastugaskan (Jordan, 2018). Dua kejadian ini menjadi penanda betapa pentingnya peran admin media sosial pemerintah dalam menjaga reputasi instansi maupun pejabat publiknya.

Sebagai kelompok pengguna media sosial instansi pemerintah, admin media sosial adalah orang yang bertanggung jawab atas akses dan penggunaan akun media sosial (Kominfo, 2018). Pengguna dapat membantu menciptakan bagaimana teknologi tertentu akan digunakan, dengan membuat interaksi antara teknologiteknologi tersebut dengan faktor-faktor pendorongnya yang ditemukan pada bagian fleksibilitas interpretatif pada SCOT (Kartika Sari \& Dkk, 2015). Dalam hal ini, pengelola/ admin sebagai pengguna menggunakan media 
sosial kementerian/lembaganya seharusnya menjadi ruang interaksi antara masyarakat dengan instansi pemerintah tersebut, sesuai tipologi web 2.0, serta menjadi utilitariandriven dengan memberikan layanan publik kepada masyarakat.

Penelitian ini bertujuan untuk menggambarkan bagaimana pengelola media sosial instansi pemerintah, dalam hal ini kementerian/lembaga pemerintah, menginterpretasikan teknologi Web 2.0 dalam bentuk media sosial berdasarkan perspektif SCOT. Penelitian ini ingin memberikan rekomendasi, dalam pengembangan konsep SCOT dalam konteks lingkungan birokrasi.

\section{METODE PENELITIAN}

Penelitian ini menggunakan pendekatan kualitatif.Penelitiankualitatifmerupakanstrategi penelitian yang biasanya lebih menekankan pada kata-kata daripada kuantitatif dalam pengumpulan dan analisis data (Bryman, 2012). Paradigma yang digunakan dalam penelitian ini adalah konstruksionisme. Paradigma konstruksionisme sosial meninggalkan gagasan konstruktivis bahwa pikiran individu mewakili cermin realitas. Konstruksionisme berfokus pada hubungan dan menopang peran individu dalam konstruksi realitas sosial. Peta pada konstruksionisme terbentuk dari pengalaman individu dan bagaimana mereka melihatnya. Masing-masing dari individu menciptakan dunianya sendiri dari persepsinya tentang dunia yang sebenarnya (Galbin, 2014). Nilai, norma, dan interpretasi masing-masing kelompok dari artefak yang sedang berkembang, dalam hal ini kelompok pengguna, dipengaruhi oleh situasi sosial, budaya, dan politik yang unik dari kelompok itu sendiri (Fulk \& Yuan, 2017). Dengan menggunakan konstruksionisme, penelitian ini menggambarkan interpretasi dan konstruksi sosial yang dimiliki oleh pengelola/ admin media sosial kementerian/lembaga pemerintah terhadap teknologi Web 2.0, yaitu media sosial, berdasarkan pengalaman yang dialami dan realitas yang dilihat oleh masingmasing informan.

Sampel yang digunakan dalam penelitian ini adalah purposive sampling karena disesuaikan dengan tujuan penelitian dan kriteria yang telah ditentukan. Kriteria informan adalah mereka yang menjadi pengelola/admin media sosial kementerian/lembaga pemerintah.

Konstruksionisme dapat terletak pada penekanan orang-orang yang diwawancara dan pengalaman orang-orang yang signifikan terkait topik yang diangkat (Bryman, 2012). Sehingga metode pengumpulan data penelitian ini adalah wawancara mendalam dengan tiga informan yang termasuk pengelola/admin media sosial kementerian/lembaga pemerintah. Ketiganya 
bekerja di departemen/bagian terkait kehumasan di level pusat kementerian/lembaga tempatnya bekerja. Pengelola media sosial pemerintah umumnya bertugas di bagian/bidang terkait kehumasan.

Informan 1, AM, perempuan, pengelola/ admin media sosial di Kementerian A. Latar belakang pendidikannya S2 Komunikasi Pembangunan. Ia sudah bekerja di Kementerian A sejak tahun 2010 dan mulai menangani media sosial Kementerian A sejak akhir tahun 2017. Sehari-hari, secara spesifik ia bertanggung jawab terhadap pengelolaan akun Twitter Kementerian A.

Informan 2, BS, laki-laki, pengelola/ admin media sosial di Lembaga Pemerintah B. Berlatar belakang pendidikan S2 Ekonomi Kependudukan dan Ketenagakerjaan. Dengan masa kerja di Lembaga B sejak tahun 2003, ia didapuk menjadi koordinator tim pengelolaan media sosial di Lembaga B sejak Januari 2017. Selain menjadi koordinator, ia juga sering kali membantu pengelolaan akun Facebook dan Instagram Lembaga B.

Informan 3, PP, perempuan, pengelola/ admin media sosial di Kementerian C. Latar belakang pendidikannya adalah S2 Manajemen Komunikasi. Ia sudah mengabdi di Kementerian C sejak tahun 2006 dan bergabung dengan tim pengelolaan media sosial Kementerian $\mathrm{C}$ selama 2,5 tahun. Sebelumnya, ia mengelola media sosial satuan kerja di bawah Kementerian

C. Saat ini, ia dipercaya mengelola akun Twitter Kementerian C.

Dari informasi yang diberikan ketiga informan, ketiganya termasuk ke dalam kelompok sosial yang relevan berdasarkan perspektif SCOT. Individu maupun kelompokkelompok yang memiliki pemahaman atau makna yang serupa terhadap suatu teknologi dapat dikategorikan dalam suatu kelompok sosial relevan yang sama (Octavianto, 2014). Para informan merupakan kelompok sosial relevan yang tergolong ke dalam kelompok users (pengguna) karena ketiganya menghadapi dan menggunakan langsung artefak teknologi dalam keseharian pekerjaannya, yaitu media sosial kementerian/lembaganya serta memiliki pemahaman yang sama terhadap media sosial.

Sehubungan dengan pandemi Covid-19 yang terjadi saat penelitian ini berlangsung, maka tidak memungkinkan peneliti untuk mewawancarai langsung informan menggunakan komunikasi tatap muka. Namun, semua informan diwawancarai secara mendalam menggunakan media synchronous, melalui telepon. Media synchronous memungkinkan komunikasi terjadi pada waktu yang sama di tempat yang berbeda (Chen et al., 2007). Wawancara informan dilakukan dengan tipe wawancara terstruktur. Untuk menjaga etika penelitian, peneliti tidak mengungkapkan nama 
informan, melainkan menggunakan inisial nama, serta tidak mengungkapkan terkait identitas kementerian/lembaga, di mana ketiga informan bernaung.

Hasil temuan dianalisis menggunakan open coding, axial coding, dan selective coding. Data hasil wawancara dianalisis dengan konsep SCOT melihat interpretasi keseluruhan dari pengelola/admin media sosial kementerian/ lembaga pemerintah yang termasuk pada kelompok sosial relevan terhadap teknologi Web 2.0.

\section{HASIL DAN PEMBAHASAN}

Dari hasil wawancara dengan ketiga informan, ditemukan bahwa ketiga informan menginterpretasikan kehadiran media sosial bagi kementerian/lembaga pemerintah sangat penting. Media sosial dapat menjadi sarana komunikasi kementerian/lembaga kepada masyarakat, baik untuk menyosialisasikan kebijakan, mengenalkan kementerian/lembaga, melakukan kontra narasi terkait kebijakan yang dikeluarkan, serta mendekatkan masyarakat kepada kementerian/lembaga tersebut. Informan BS memahami bahwa bagi lembaga pemerintah, media sosial merupakan media publisitas yang banyak digunakan saat ini karena murah, cepat, dan jangkauannya luas

"Karena dia sebagai media publisitas, sosialisasi yang cepat, murah, dan jangkauannya luas. Kalau dulu orang mau mengomunikasikan sesuatu, selama ini di seminar atau press release. Atau acara sosialisasi yang perlu dipersiapkan jauhjauh hari. Kalau sekarang dengan kehadiran media sosial menjadi alat komunikasi paling cepat dalam mensosialisasikan.”

Sementara, dilihat dari sisi masyarakat, informan PP menginterpretasikan media sosial sudah menjadi bagian dari kehidupanmasyarakat saat ini, terutama masyarakat yang memiliki kemampuan dan keterjangkauan pada internet. Kondisi seperti itu yang akhirnya membuat media sosial begitu penting peranannya dalam memberikan informasi kepada masyarakat.

"Menurut gue penting ya karena urusan instansi kita sangat luas. Apalagi di saat ini, di saat pandemi, orang-orang ngakses medsos. Untuk daerah-daerah orang-orang di mana internet adalah keniscayaan, listrik ada gitu. Dia mau ngapain lagi? Dia pasti ngakses media sosial lewat internet gitu. Jadi tantangannya adalah nyampein kebijakan atau aturan yang mungkin bahasanya rumit atau bahasanya hukum menjadi sesuatu yang sederhana. Jadi kalimat-kalimat sederhana yang bisa dipahami masyarakat, tapi itu penting. Supaya makin banyak yang ngerti maksudnya pak menteri itu apa, maksudnya kementerian kita itu apa.”

Informan AM menginterpretasikan media sosial saat ini juga menjadi concern pemerintahan sekarang, sehingga kementerian/ lembaga pemerintah pun harus sejalan dengan hal tersebut. Media sosial memberikan tantangan baru bagi pemerintah dalam menjalankan fungsi kehumasan yang lebih interaktif dengan jangkauan yang lebih luas dan penetrasi informasi seketika dalam public relation (PR) 
2.0 (Kurniasih, 2016). Oleh karena itu, segenap jajaran kementerian/lembaga harus peduli dan paham akan pentingnya penggunaan media sosial bagi kementerian/lembaga.

"Saat ini sih sudah dianggap sangat penting. Karena yang pertama, kita akui bahwa Presiden itu sangat memandang penting media sosial. Nah menteri gue sekarang termasuk yang aktif di media sosial, benerbener melihat juga konten dan keaktifan kita humas di media sosial, dinilai oleh beliau. Pada akhirnya, karena pimpinannya yang concern terhadap media sosial, mau enggak mau ke bawahnya juga memandang penting media sosial."

Seseorang yang tergabung ke dalam kelompok sosial relevan dapat mengidentifikasi tiga jenis fleksibilitas yang semuanya saling berhubungan dalam konstruksi sosial teknologi, yaitu fleksibilitas bahasa, fleksibilitas penggunaan, dan fleksibilitas struktur. Fleksibilitas bahasa mengacu pada fleksibilitas interpretatif sebuah artefak. Pinch dan Bijker menjelaskan bahwa gagasan kelompok sosial yang berbeda dapat memiliki arti yang berbeda dan wacana tentang artefak teknologi (Humphreys, 2006). Dari informasi yang diberikan informan, fleksibilitas interpretatif masing-masing informan terhadap teknologi Web 2.0, dalam hal ini media sosial kementerian/ lembaganya cenderung sama. Namun, dalam fleksibilitas pengunaannya berbeda, terutama dalam berinteraksi dengan warganet (followers akun media sosial kementerian/lembaga mereka). Sebagaimana karakteristik Web 2.0 yang merupakan web partisipatif, di mana orang dapat membaca dan menulis informasi untuk dibagikan atau bersifat interaktif dua arah (Patel, 2013).

Ketiga informan menggunakan ruang media sosial kementerian/lembaganya untuk memenuhi kebutuhan kementerian/lembaganya dalam menyebarluaskan informasi kepada masyarakat. Berdasarkan tipologi Web 2.0, ruang media sosial kementerian/lembaga pemerintah dirancang seperti metafora utilitarian-driven, di mana sifat ruang media sosial difungsikan berdasarkan tujuan dan manfaat bagi masyarakat, dalam hal ini sebagai bentuk layanan kepada masyarakat (Arora, 2012). Media sosial saat ini dijadikan sebagai pintu pertama informasi tentang kementerian/ lembaga oleh masyarakat, sehingga admin harus siap sedia merespon dan menanggapi warganet. Informan BS mengatakan konsekuensi lembaga memanfaatkan media sosial, salah satunya dalam menghadapi segala bentuk respon, kritik, dan masukan dari masyarakat.

Mengelola ruang interaksi dalam media sosial kementerian/lembaga pemerintah diakui ketiga informan menjadi tantangan tersendiri. Interaksi yang diciptakan masing-masing informan sebagai pengelola/admin media sosial kementerian/lembaga pemerintah mengarah pada bagaimana mereka merespon pertanyaan atau komentar dari warganet. Informan BS 
mengaku bahwa konten yang disampaikan media sosial lembaganya sebagian besar masih bersifat informatif atau satu arah, dibanding konten yang bersifat menggugah interaksi warganet (komunikasi dua arah). Hal ini disadarinya karena minimnya sumber daya manusia dalam tim pengelolaan media sosial lembaganya yang tidak secara khusus mengelola media sosial, namun juga mengerjakan pekerjaan rutin kehumasan lainnya.

Sementara informan AM, dalam mengelola media sosial bersama timnya berupaya tanggap terhadap isu terkini. Isu-isu yang sedang hangat dibicarakan terkait dengan Kementerian A, berupaya dijawab melalui akun media sosial Kementerian A agar memperoleh dampak pemberitaan yang luas di media arus utama. Jurnalisme hibrida yang marak saat ini memungkinkan apa yang disampaikan di media sosial dikutip oleh media lainnya. Selebihnya, konten yang diunggah Kementerian A bersifat normatif, seperti informasi kegiatan menteri atau kebijakan yang perlu disebarluaskan.

Pengelolaan media sosial yang dilakukan informan PP bersama timnya berupaya mendapat respon dari warganet, baik positif maupun negatif. Tak sekadar memberikan informasi satu arah, dalam penyampaian pesannya, informan PP mencoba merangsang tanggapan dari warganet atas konten yang diunggah. Walaupun terdapat rubrik harian di akun media sosial Kementerian C, namun pada waktu-waktu tertentu informan PP beserta tim mengunggah konten yang bertujuan ingin mengetahui pendapat warganet tentang kebijakan atau segala hal tentang Kementerian C.

Ada kesamaan di antara ketiga informan dalam mengelola ruang interaksi antara pengelola/admin media sosial kementerian/ lembaga pemerintah dengan warganet, yaitu tidak semua tanggapan atau komentar dari warganet yang direspon oleh informan sebagai pengelola/admin media sosial. Dari kesamaan tersebut, cara merespon dan berinteraksi di ruang media sosial kementerian/lembaga berbeda satu sama lain. Pertimbangan memilih komentar yang direspon oleh pengelola/admin media sosial memperlihatkan fleksibilitas interpretatif masing-masing informan terhadap ruang interaksi di media sosial. Informan AM melihat beragamnya kepentingan warganet di akun media sosial Kementerian A membuat pengelola/admin media sosial memilah komentar warganet yang harus direspon. Urgenitas topik yang dikomentari menjadi prioritas yang harus direspon oleh admin.

"Ya paling pilih salah satu ya. Ini juga kalau di Twitter kita lihat juga ya, kalau enggak terlalu urgent, ya enggak usah di kultwit ya, cukup di-reply aja. Tapi kita membedakan sih, kita telusur juga ini emang netizen yang bener ingin bertanya atau buzzerbuzzer juga banyak juga kan ya. Tapi kita tetep dalam koridor diplomatif ya. Kita menjaga." 
Dengan tujuan sosialisasi untuk mendorong partisipasi warganet terhadap program yang sedang digulirkan lembaga membuat sebagian besar pertanyaan atau komentar warganet ditanggapi pengelola/admin media sosial Lembaga B. Media sosial, pada konteks tersebut, dijadikan sebagai rujukan utama bagi warganet untuk bertanya tentang program yang tengah berlangsung. Namun, cara menanggapi pertanyaan atau komentar warganet dibedakan oleh informan BS, tergantung sensivitas isu atau topik yang dibicarakan. Kolom komentar digunakan informan BS dan timnya untuk menanggapi atau merespon komentar yang bersifat umum. Sementara untuk topik yang sensitif, jawaban atau tanggapan dialihkan melalui direct message (DM), hanya penanya yang dapat berinteraksi dengan admin.

"Kalau harus selalu ditanggapi sih enggak, namun selama program yang sekarang dijalankan ini kan konten di media sosial lebih banyak tentang itu. Itu sebagian besar pertanyaan dari netizen kita jawab. Tapi kalau ada pertanyaan yang detail dan berpotensi jika dijawab maka akan memperlebar masalah, maka kita enggak jawab langsung tapi kita komunikasikan ke tim atau kita tanyakan ke subject matter. Nah yang terjadi, yang pernah kita alami, saran dari subject matter, maka jawabnya melalui DM bukan komen."

Sementara bagi informan PP, pengalaman pengelola/admin media sosial menentukan bagaimana admin menghadapi warganet. Hal tersebutmemperlihatkan pemahaman pengelola/ admin media sosial terhadap cara kerja di media sosial. Digital savvy diperlukan bagi pengelola media sosial, sebagai pemahaman, yang dikembangkan melalui pengalaman dan pendidikan, dari dampak teknologi yang muncul yang akan berpengaruh pada kesuksesan organisasi (Weill et al., 2019). Sebagai admin media sosial, diperlukan pemahaman seluk beluk media sosial dan ekosistem digital, serta mau sepenuhnya mencurahkan pemikirannya untuk mengelola media sosial.

"Yang perlu direspon ya. Jadi memang itu jam terbang ya menurut gue. Jadi pada sampai lo enggak baper dan lo memang bisa nilai mana yang harus direspon mana yang enggak itu seiring waktu sih sebenernya. Lo tahu seluk beluknya. Itulah makanya lo perlu orang yang penuh dedicated pegang medsos itu. Menurut gue sih dan menurut gue teman-teman lain sepakat pengelolaan medsos itu enggak bisa disambi. Itu kan masalah-masalah selama ini di satker mana pun di kementerian, itu gitu. Enggak mudah itu ngurus medsos."

Selain fleksibilitas interpretatif, terdapat fleksibilitas penggunaan, sebagaimana dijelaskan oleh MacKay dan Gillespie bahwa pengguna dapat menggunakan artefak secara berbeda. Teknologi menawarkan berbagai kemungkinan untuk penyesuaian. Keterbukaan dan ketertutupan artefak berkaitan dengan kemungkinan penggunaannya dan fleksibilitasnya yang lebih besar dalam pemaknaan (Humphreys, 2006). Ketiga informan menyadari penuh tanggung jawabnya menjaga reputasi kementerian/lembaga 
pemerintah dalam menggunakan media sosialnya. Dalam hal ini, artefak teknologi memiliki sifat yang tertutup karena dalam penggunaannya menawarkan fleksibilitasnya yang sedikit, tidak sebesar ketika media sosial digunakan untuk kepentingan pribadi. Termasuk informan AM ketika memilih menggunakan akun pribadi pegawai untuk merespon warganet yang menghujat Kementerian A semata-mata, untuk menjaga persona akun media sosial Kementerian A.

"Kalau kita kan sebagai admin balik lagi karena memang kementerian kan menjaga personanya. Personanya diplomatis ya. Hati-hatilah, lebih hati-hati dalam merespon gitu.. Kalau teman-teman kita yang menggunakan akun pribadi kan akan lebih leluasa untuk menjawab.”

Terdapat sejumlah aturan atau Standard Operating Procedures (SOP) yang memandu dan mengarahkan informan, baik secara lisan maupun tertulis dalam menggunakan media sosial kementerian/lembaganya. Improvisasi dari aturan yang sudah ada kerap dilakukan ketiga informan, mengingat dinamika media sosial yang ada. Namun, improvisasi tersebut tidak menyalahi SOP. Tim media sosial di kementerian informan PP bekerja sesuai SOP yang ada, bahkan ketika ada permintaan atau arahan terkait konten media sosial yang tidak sesuai dengan SOP, maka tim media sosial akan menolaknya.

Komponen lainnya dalam SCOT adalah penutupan dan stabilitas. Penutupan sebagai titik di mana kelompok sosial yang relevan menganggap masalah mereka dengan artefak terpecahkan. Stabilisasi didefinisikan proses di mana anggota kelompok sosial yang relevan datang untuk mengomunikasikan definisi dan spesifikasi artefak yang serupa dari waktu ke waktu (Humphreys, 2006). Menurut Bijker, penutupan dan stabilisasi adalah dua sisi dari mata uang yang sama. Penutupan berfokus pada makna yang dikaitkan oleh berbagai kelompok sosial yang relevan dengan artefak, sementara stabilisasi berfokus pada pengembangan artefak itu sendiri dalam satu kelompok sosial yang relevan, terkait modalitas yang digunakan dalam deskripsinya (Humphreys, 2006). Stabilisasi dapat dicapai dengan rhetorical closure (penutupan retoris) dan closure by redefinition (mendefinisikan kembali masalah) (Fulk \& Yuan, 2017).

Rhetorical closure terjadi ketika suatu pernyataan dibuat bahwa tidak ada masalah lebih lanjut dan tidak ada desain tambahan yang diperlukan. Closure by redefinition terjadi ketika masalah yang belum terselesaikan didefinisikan ulang, sehingga tidak menimbulkan masalah pada kelompok sosial lagi (Klein \& Kleinman, 2002).

Ketiga informan dalam mendefinisikan penutupan dan mencapai stabilitas cenderung menggunakan closure by redefinition atau 
mendefinsikan kembali masalah sehingga sudah tidak dianggap masalah oleh informan. Informan AM dan BS melakukan penutupan dan stabilisasi terkait bagaimana interaksi admin dengan warganet berkenaan isu atau topik bersifat teknis. Terdapat kesamaan produk atau output antara Kementerian A dan Lembaga B kepada masyarakat, walaupun berada dalam ranah berbeda. Isu atau topik bersifat teknis terkadang tidak mampu ditangani oleh pengelola/admin media sosial. Di satu sisi, admin bertanggung jawab untuk segera merespon komentar warganet, namun di satu sisi, adanya keterbatasan pengetahuan admin mengenai produk kementerian/lembaga yang begitu luas. Untuk mengatasi hal tersebut, admin media sosial mendefinisikan masalah dengan berkoordinasi dengan tim teknis di kementerian/ lembaganya masing-masing. Dengan cara tersebut, tercapai sebuah stabilisasi pada tim pengelolaan media sosial informan AM dalam menangani persoalan serupa di kemudian hari.

"Nah yang bingung kalau di kita kan teknis banget. Hal-hal yang benar-benar kondisi di lapangan kan. Nah itu gimana kita butuh LO (liaison officer, red) di masing-masing eselon I itu jawab masalah-masalah teknis. Kalau dia ngerti dia pasti langsung jawab kan gini. Kalau dia enggak ngerti, dia pun akan menanyakan, bentar ya gue tanya dulu ke direktorat mana." (Informan AM)

Seperti halnya Informan AM, Informan BS juga mendefinisikan masalah dengan berkoordinasi dengan subject matter (sebutan unit kerja lain yang menangani masalah terkait).

Koordinasi tersebut dilakukan jika di dalam tim media sosial tidak mampu menangani masalah secara detail.

"Di panduan media sosial kita seingat saya belum ada. Padahal pertanyaan tentang teknis itu kan sering muncul tuh. Ketika itu muncul, maka dibutuhkan pemaparan dari subject matter atau saya nanya ke subject matter. Jika mereka (admin, red) menemukan masalah yang mereka tidak tahu jawabannya, maka mereka akan menanyakan di grup dan kita saling memberikan informasi. Sementara untuk pertanyaan-pertanyaan yang bisa mereka jawab karena kemampuan mereka menjawab dan diskusi dengan subject matter dari hari ke hari, juga pengalaman kerja, mereka yang jawab." (Informan BS)

Redefinisi masalah yang dilakukan informan PP terkait dengan pemahaman informan terhadap kultur di dalam media sosial yang menjadi tanggung jawabnya, yaitu di Twitter. Dibanding platform lainnya, Twitter kerap dijadikan arena pertarungan politik dalam situasi dan kondisi politik saat ini. Para pemangku kepentingan kerap menggunakan Twitter untuk mengekspresikan emosi tertentu (Brummette \& Fussell, 2015). Oleh karena itu, admin media sosial perlu memahami kondisi publik di ruang digital untuk mewaspadai konten yang terdapat kemungkinan dikaitkan dengan isu politik atau isu sensitif lainnya. Untuk meredefinisi masalah tersebut, informan PP berupaya memandang hal tersebut dari sisi berbeda, sisi yang menguntungkan bagi akun media sosial Kementerian C, yaitu bisa 
menambah followers.

"Apa pun yang dilempar di Twitter sekarang ini, beberapa tahun belakangan ini, bisa jadi amunisi untuk jadi tweet war. Apalagi zaman Pemilu tahun lalu (2019, red). Jadi kita mesti ekstra hati-hati karena di Twitter itu orang perang. Gampang banget apa yang kita sampaikan dihubungkan kita dukung yang kanan atau yang kiri. Kalau salah, ya salah aja. Salah, terus diamplifikasi, dijadiin sesuatu yang besar, semua orang tahu..... Blessing in disguise-nya adalah follower kita nambah banyak banget...."

Keputusan informan PP untuk menangani langsung konten Twitter yang akan diunggah dirasakan menjadi kendala ketika dirinya tidak dapat melakukan fungsinya sebagai admin. Informan PP melakukan penutupan dan mencapai stabilisasi dengan berkoordinasi dengan rekan setim atau penundaan penayangan konten.

Selain berupaya mencapai stabilisasi dan penutupan dengan meredefinisi masalah, informan PP beserta tim juga melakukan penutupan retoris. Bagi informan PP dan tim, krisis komunikasi di media sosial merupakan hal yang wajar, sehingga penanganan krisis sudah mampu dilewati belajar dari pengalaman sebelumnya.

"Kalau ada kendala dari kayak krisis komunikasinya, kalau kita itu udah biasa banget deh. Bisa jadi potensi untuk menambah follower dan meningkatkan engagement, kita lihatnya ke situ. Kalau satker ngadepin masalah masih panik, kalau kita udah lempeng aja kayak biasa. Itu kan jam terbang ya. Ada yang enggak bisa enggak diatasin. Udah gitu orang Indonesia gampang lupa, ya udah gitu."
Terakhir, dalam komponen SCOT menurut Pinch dan Bijker sebagai pengembangan konsep awal SCOT adalah the wider context. Situasi sosiokultur (sociocultural) dan politik dianggap Pinch dan Bijker berkontribusi dalam pembentukan norma dan nilai-nilai yang dianut oleh kelompok sosial yang relevan dalam mengonstruksi makna artefak teknologi yang digunakan (Octavianto, 2014). Lebih khusus, aspek sosiokultur dan politik dapat terlihat pada proses fleksibilitas interpretatif dan stabilisasi.

Pada temuan di lapangan, dalam menghadapi artefak teknologi, yaitu media sosial kementerian/lembaga pemerintah, unsur the wider context sangat terlihat dari ketiga informan. Dalam menggunakan teknologi media sosial, para pengelola/admin media sosial tidak dapat terlepas dari sosiokultur dan politik di tempatnya bekerja. Pemahaman akan posisi pengelola/admin media sosial yang berstatus pegawai di kementerian/lembaga tersebut menjadi kontrol bagi admin untuk mematuhi segala aturan di dalam kementerian/lembaga, mengesampingkan kepentingan pribadi. Dalam konteks kementerian/lembaga pemerintah, informan memposisikan diri sebagai pegawai sekaligus sebagai garda terdepan komunikasi publik kementerian/lembaganya dengan masyarakat. Posisi media sosial kementerian/ lembaga pemerintah pun menjadi perwajahan pemerintah Indonesia, karena merupakan 
lembaga yang selalu sejalan dengan visi misi pemerintah. Perwajahan di media sosial juga terkait persepsi masyarakat terhadap citra pemerintah. Selama ini, kementerian/lembaga pemerintah dipandang sebagai sebuah institusi yang kaku, namun komunikasi publik melalui media sosial diharapkan mampu menciptakan berbagai kreativitas yang dapat menarik warganet untuk mengikuti dan terlibat dalam informasi yang ada di media sosial pemerintah.

Informan PP memahami bahwa kultur di dalam ruang media sosial yang dikelolanya, yaitu Twitter mengalami perubahan secara budaya. Web 2.0 menandai momen budaya yang lebih luas (Barassi and Treré, 2012). Saat ini, Twitter kerap menjadi arena politik, apalagi dengan karakteristiknya yang memungkinkan siapapun mengekspresikan emosi dan pandangannya yang terjangkau banyak orang. Pemahaman akan hal ini membuat informan PP menjadi lebih berhati-hati dalam mengunggah konten, berkomentar, ataupun ketika berinteraksi dengan warganet di Twitter.

Berdasarkan itu pula lah, informan PP beserta timnya berupaya menjaga ruang media sosial Kementerian $\mathrm{C}$ untuk tidak diintervensi oleh siapapun, namun diberi kebebasan dalam pengelolaannya. Intervensi dimaksud adalah permintaan untuk mengunggah konten yang tidak sesuai dengan SOP yang ada. SOP yang disusun meliputi tata bahasa, tata desain, kejelasan informasi, format penulisan, dan lainlain. Setiap pembuat dan pengirim konten wajib mematuhi SOP sebagai bagian dari menjaga persona akun media sosial Kementerian $\mathrm{C}$. "Di medsos itu kita tuh bener-bener pokoknya mesti atasan kita minta disuruh sosialisasiin A, B, C. Bentar ya Pak antri, giliran, banyak yang mau di-posting. Kita gituin aja langsung. Ini terlalu padat Pak tulisannya. Misalnya titipan dari satker lain. Ini kita mau edit dulu. Jadi kalau ada yang bilang kita lambat, lama, lambat, mereka juga harus tahu apa yang mereka kasih itu sudah memenuhi standar belum?"

Kewaspadaan dalam mengelola media sosial pemerintah dipahami semua informan menjadi kewajiban sekaligus konsekuensi. Terdapat nama besar kementerian/lembaga pemerintah dan menteri/kepala lembaga yang perlu dijaga di publik. Oleh karena itu, kesalahan mesti dihindari untuk menjaga reputasi kementerian/lembaga. Informan AM menceritakan pernah terjadi kesalahan dalam berkomentar di tim media sosial kementerian yang berimbas luas dan menyinggung politik. "Itu kan sensitif politik, karena masih rame kan waktu itu. Dia posting kayak menyampaikan pendapatnya soal politik. Itu jadi berlawanan sama pemerintah, oposisinya pemerintah lah. Dipretelin gitu adminnya. Dia itu kerjanya apa. Ya semacam itu lah. Ya rame... ya pengelolaan itu akan jadi masalah karena ada kesalahan yang dilakukan kan.”

Pengalaman tersebut dijadikan informan AM dan tim untuk lebih waspada dalam berinteraksi dengan warganet. Ia pun pernah melakukan kesalahan dalam mengeluarkan 
konten di media sosial Kementerian A dan diminta penjelasan langsung oleh pimpinannya.

Informan BS bersama timnya pun pernah mendapatkan kritik dari warganet terkait kreativitas konten yang dibuat. Tujuan edukasi terhadap produk lembaga yang dilakukan dipahami berbeda, sehingga menimbulkan kritikan para warganet. Disatu sisi, engagement konten saat itu meningkat tajam. Karena reaksi keras warganet, pimpinan lembaga meminta mereka menurunkan konten tersebut. Pengalaman ini membuat informan BS dan timnya lebih berhati-hati dalam memproduksi konten karena pengelolaan media sosial di lembaganya masih dijalankan secara normatif. Hal ini juga tak terlepas dari instruksi pimpinan yang belum memahami secara luas cara kerja ruang media sosial.

"Dulu kita pernah memprediksi dengan apa metode (produk lembaga B, red), mana nih peluangnya yang lebih besar untuk menang. Kita posting karena itu tujuannya untuk mendekatkan ke publik terus viral. Viralnya yang negatif, dianggapnya lembaga B kenapa nih adminnya malah mem-posting hal yang enggak penting. Itu sampai ke pimpinan harus di-take down. Di titik itu saya merasa dari sisi konten menarik tapi dari sisi pimpinan itu enggak siap ketika dikritik oleh banyak orang. Di situlah menariknya saya jadi tahu untuk saat ini kita main di zona aman."

Terkait hal ini, jika dibandingkan kultur organisasi di Kementerian C, tempat informan PP bernaung, lebih fleksibel dalam menerima berbagai kreativitas untuk konten media sosial.
Walaupun ada instruksi dari pejabat lembaga, namun tim informan PPterlihat lebih independen dan berupaya meminimalkan intervensi dari luar tim terkait pembuatan konten media sosial. Informan PP beserta timnya merasa pemahaman mereka terhadap ruang media sosial dapat diandalkan, sehingga mendapatkan kebebasan lebih untuk mengelola media sosial. Walaupun diberikan ruang lebih lebar terhadap peluang improvisasi pengelolaan media sosial, namun informan PP dan timnya bertanggung jawab penuh terhadap segala konsekuensi yang dihadapi.

Dari informasi yang dikumpulkan dari ketiga informan menunjukkan bahwa konstruksi sosial teknologi media sosial yang digunakan oleh informan sebagai pengelola/admin media sosial pemerintah tak terlepas dari konteks yang lebih luas, yaitu kultur organisasi, pemahaman struktur lain (pimpinan, satuan kerja, unit kerja lain) terhadap media sosial, persepsi warganet terhadap kementerian/lembaga pemerintah, serta kondisi politik yang sedang berkembang. Konteks ini tidak terlepas dari budaya organisasi kementerian/lembaga yang bersifat birokratis.

Interpretasi terhadap teknologi Web 2.0 oleh ketiga informan yang merupakan pengelola/admin media sosial kementerian/ lembaga pemerintah berdasarkan perspektif SCOT terlihat pada Tabel 1.

Berdasarkan perspektif Social Construction 
Tabel 1 Konstruksi Sosial Admin Media Sosial terhadap Web 2.0 (Media Sosial)

\begin{tabular}{clll}
\hline Informan & Fleksibilitas Interpretatif & Penutupan dan Stabilisasi & \multicolumn{1}{c}{ The Wider Context } \\
\hline AM & Pemenuhan informasi & Closure by redefinition, & Independensi tim \\
& kementerian kepada & terkait isu teknis di & terhadap iklim \\
& masyarakat. Interaksi & kementerian. & politik yang sedang \\
& cenderung normatif, & & berkembang. \\
& informatif, dan satu arah. & & \\
Pemenuhan informasi & Closure by redefinition, & Pemahaman struktur \\
& lembaga kepada & terkait isu teknis yang & lain, yaitu pimpinan \\
& masyarakat. Interaksi & merupakan produk & dan unit kerja lain, \\
& cenderung normatif, & lembaga. & serta persepsi warganet \\
informatif, dan satu arah. & & terhadap lembaga. \\
Pemenuhan informasi & Closure by redefinition & Kultur organisasi lebih \\
& kepada msyarakat. Interaksi & dengan pemahaman & terbuka akan kreativitas, \\
terkadang mendorong & karakteristik platform. & sehingga tim lebih \\
partisipasi warganet untuk & Rhetorical closure dalam & independen dalam \\
terciptanya interaksi dua & menghadapi masalah dan & mengelola media sosial. \\
arah. & konsekuensinya. & \\
\hline
\end{tabular}

Sumber: Hasil Penelitian, 2020

of Technology (SCOT), ada empat komponen yang dijabarkan dalam penelitian ini, yaitu kelompok sosial yang relevan, fleksibilitas interpretatif, penutupan, dan stabilisasi (Humphreys, 2006). Pengembangan konsep awal SCOT memasukkan komponen the wider context. Dalam hal ini, interpretasi kelompok sosial relevan terhadap artefak teknologi berkaitan dengan konteks sosial, budaya, dan politik (Octavianto, 2014). Kultur sosial, budaya, politik, serta organisasi berkontribusi pada interpretasi kelompok relevan (pengelola/admin media sosial kementerian/ lembaga pemerintah) menggunakan media sosial. Fleksibilitas interpretatif atau bahasa pemaknaan informan terhadap teknologi Web 2.0 terkait dengan kegunaan media sosial bagi kementerian/lembaga dan ruang interaksi di media sosial yang digunakan mereka.

Penutupan sebagai titik di mana kelompok sosialyangrelevan menganggap masalah mereka dengan artefak terpecahkan (Humphreys, 2006) 
berkaitan dengan bagaimana koordinasi mereka dengan struktur lain di dalam organisasi. Penutupan dan stabilisasi adalah dua sisi dari mata uang yang sama (Humphreys, 2006), sehingga ketika masalah sudah terpecahkan di penutupan, maka informan melakukan stabilisasi dengan melakukan yang cara sama di kemudian hari. Begitu pun dengan rhetorical closure cenderung pada bagaimana informan menghadapi masalah dalam penggunaan media sosial serta konsekuensi yang didapatkan.

\section{SIMPULAN}

Fleksibilitas interpretatif pengelola/ admin media sosial kementerian/lembaga cenderung sama, namun tata kelola atau cara kerja di masing-masing organisasi yang membedakannya. Ketiga informan menginterpretasi penggunaan media sosial menjadi sarana komunikasi publik kementerian/ lembaga kepada masyarakat, baik untuk menyosialisasikan kebijakan, mengenalkan kementerian/lembaga, melakukan kontra narasi terkait kebijakan yang dikeluarkan, serta membangun hubungan/interaksi masyarakat kepada kementerian/lembaga tersebut.

Fleksibilitas interpretatif pengelola/admin media sosial juga tergambar pada bagaimana mereka berinteraksi memberikan layanan publik, sesuai fungsi media sosial sebagai utilitarian driven, dengan merespon pertanyaan ataupun komentar di akun media sosial kementerian/lembaganya. Faktor pendorong pengelola/admin media sosial merespon adalah pada urgenitas dan sensivitas topik yang ditanyakan.

Fleksibilitas penggunaan ketiga informan dalam menggunakan media sosial kementerian/ lembaga pemerintah memperlihatkan kewaspadaan informan dalam menjaga reputasi kementerian/lembaganya. Dalam hal ini, artefak teknologi memiliki sifat yang tertutup karena dalam penggunaannya menawarkan fleksibilitasnya yang sedikit, tidak sebesar ketika media sosial digunakan untuk kepentingan pribadi. Terdapat sejumlah aturan atau Standard Operating Procedures (SOP) yang memandu dan mengarahkan informan, baik secara lisan maupun tertulis dalam menggunakan media sosial kementerian/lembaganya. Menjadi admin media sosial juga perlu memiliki digital savvy, yaitu pemahaman akan dampak teknologi terhadap lembaga agar mampu mengelola media sosial kementerian/lembaga sesuai dengan visinya. Pemahaman didapatkan admin media sosial, baik melalui pengalaman maupun pengetahuan yang dimiliki.

Pada komponen penutupan dan stabilitas, pengelola/adminmediasosialmendefinisikannya dengan menggunakan closure by redefinition atau mendefinisikan kembali masalah. Redefinisi masalah menyangkut pada isu yang 
bersifat teknis serta interpretasi pengelola/ admin media sosial akan kultur yang ada di media sosial. Rhetorical closure (penutupan retoris) atau penutupan retoris dilakukan dengan bagaimana menghadapi masalah dan mengukur konsekuensi yang dihadapi. Hal ini terkait permasalahan yang dihadapi di media sosial.

Dalam menggunakan teknologi media sosial di kementerian/lembaganya, konteks sosiokultur dan politik memberikan kontribusi pada konstruksi sosial informan terhadap artefak teknologi. Penelitian ini melihat adanya konteks yang lebih luas (the wider context) berupa kultur organisasi, pemahaman struktur lain (pimpinan, satuan kerja, unit kerja lain) terhadap media sosial, persepsi warganet terhadap kementerian/lembaga pemerintah, serta kondisi politik yang sedang berkembang dalam konstruksi informan tentang penggunaan dan pengelolaan media sosial kementerian/ lembaganya. Dalam menggunakan teknologi Web 2.0, pengelola/admin media sosial di kementerian/lembaga pemerintah masih terikat pada aturan birokrasi yang ada, karena menjadi perwajahan organisasi di dalam lingkungan virtual. Pemahaman struktur organisasi, seperti pimpinan dan unit kerja lain terhadap ekosistem digital ikut berperan dalam bagaimana cara kerja penggunaan media sosial. Kultur organisasi yang terbuka membuat penggunaan media sosial memberi peluang akan kreativitas dalam tim untuk semakin berkembang. Begitu pun dengan kondisi politik yang berada di eksternal organisasi perlu dipahami sebagai faktor yang harus diperhitungkan dalam penggunaan media sosial kementerian/lembaga pemerintah yang netral. Hal ini terkait pemanfaatan media sosial saat ini untuk menyampaikan ekspresi politik masyarakat.

Penelitian ini menggambarkan bagaimana fleksibilitas interpretatif teknologi Web 2.0, dalam hal ini media sosial, bagi para pengelola/ admin media sosial kementerian/lembaga pemerintah dari perspektif SCOT. Penelitian ini memberikan sumbangsih pada pengembangan konsep SCOT, terutama dalam konteks organisasi publik atau kementerian/lembaga pemerintah yang terikat birokrasi. Penelitian ini memberikan rekomendasi bagi penelitian selanjutnya untuk mengembangkan konstruksi sosial teknologi media sosial dari sisi kelompok sosial relevan lainnya, yaitu bystanders (pengamat) untuk menggambarkan sisi yang lain dari penggunaan media sosial kementerian/ lembaga pemerintah.

\section{DAFTAR PUSTAKA}

Arora, P. (2012). Typology of Web 2.0 spheres: understanding the cultural dimensions of social media spaces. Current Sociology, 60(5), 599-618. https://doi. org/10.1177/0011392112440439

Barassi,V.,\&Treré,E.(2012).DoesWeb3.0come 
after Web 2.0? Deconstructing theoretical assumptions through practice. New Media and Society, 14(8), 1269-1285. https://doi. org/10.1177/1461444812445878

Binsar, A., \& Salamah, U. (2018). Anticipating the Post human era in public relations. 2nd Indonesia International Graduate Conference on Communication (IndoIGCC) Proceeding, 373-392.

Brummette, J., \& Fussell, H. (2015). Public relations review using twitter as a means of coping with emotions and uncontrollable crises. Public Relations Review, 41(1), 89-96. https://doi.org/10.1016/j. pubrev.2014.10.009

Bryman, A. (2012). Social research methods (4th editio). New York: Oxford University Press Inc.

Chen, Y.-T., Liu, C.-H., \& Wong, R. (2007). The adoption of synchronous and asynchronous media in the teaching of a second language. Issues In Information Systems, VIII(1), 217-223. https://doi.org/10.48009/1_ iis_2007_217-223

Criado, J. I., Sandoval-Almazan, R., \& GilGarcia, J.R. (2013). Governmentinnovation through social media. Government Information Quarterly, 30(4), 319-326. https://doi.org/10.1016/j.giq.2013.10.003

Fuchs, C., Hofkirchner, W., Schafranek, M., Raffl, C., Sandoval, M., \& Bichler, R. (2010). Theoretical foundations of the web: cognition, communication, and cooperation. towards an understanding of web 1.0, 2.0, 3.0. Future Internet, 2(1), 41-59. https://doi.org/10.3390/fi2010041

Fulk, J., \& Yuan, Y. C. (2017). Social construction of communication. The International Encyclopedia of Organizational Communication, 1, 1-19. https://doi.org/10.1002/9781118955567. wbieoc190

Galbin, A. (2014). An introduction to social constructionism. Social Research Reports, 6(26), 82-92.

Humphreys, L. (2006). Reframing social groups, closure, and stabilization in the social construction of technology. Social Epistemology, March 2014, 37-41. https:// doi.org/10.1080/02691720500145449

Jordan, R. (2018). Cerita admin Jokowi dibebastugaskan gegara tweet jkt48. Detik.Com. https://news.detik.com/ berita/d-4024449/cerita-admin-jokowidibebastugaskan-gegara-tweet-jkt48

Kartika Sari, D., \& Dkk. (2015). Information and communication technology dan literasi media digital. In Aspikom. https://books. google.co.id/books/about/Information and_communication_technology. html?id=4PizDAEACAAJ\&redir_esc $=y$

Kartikawangi, D. (2020). Focus group based evaluation of social media usage in Indonesia's digital government. Asian Journal for Public Opinion Research, $8(1), \quad 41-58 . \quad$ https://doi.org/10.15206/ ajpor.2020.8.1.41

Khan, G. F. (2017). Socialmedia for government. a practical guide to understanding, implementing, and managing social media tools in the public sphere. https://doi. org/10.1007/978-981-10-2942-4

Klein, H. K., \& Kleinman, D. L. (2002). The social construction of technology: structural considerations. Science Technology and Human Values, 27(1), 28-52. https://doi. org/10.1177/016224390202700102

Kominfo. (2018). Memaksimalkan penggunaan media sosial dalam lembaga pemerintah. Direktorat Jenderal Informasi dan Komunikasi Publik Kementerian Komunikasi dan Informatika. http:// 
repositorio.unan.edu.ni/2986/1/5624.pdf

Kurniasih, N. (2016). Penggunaan media sosial bagi humas di lembaga pemerintah (Issue September 2013). https://doi.org/10.13140/ RG.2.2.15820.41609

Lin, H., Fan, W., \& Chau, P. Y. K. (2014). Determinants of users' continuance of social networking sites: A self-regulation perspective. Information and Management, 51(5), 595-603. https://doi.org/10.1016/j. im.2014.03.010

Mojo. (2018). Kesalahan admin twitter akun pemerintah. Tirto.Id. https://irto.id/ kesalahan-admin-twitter-akun-pemerintahcKBM

Octavianto, A. W. (2014). Strukturasi giddens dan social construction of technology (scot) sebagai pisau analisis alternatif penelitian sosial atas teknologi media baru. Ultima Comm, VI(2), 41-57.

Patel, K. (2013). Incremental journey for world wide web: introduced with web 1.0 to recent web 5.0 - a survey paper. International Journal of Advanced Research in Computer Science and Software Engineering, 3(10), 410-417. http://www.ijarcsse.com/docs/ papers/Volume_3/10_October2013/V3I100149.pdf

Petrescu, M., \& Korgaonkar, P. (2011). Viral advertising: definitional review and synthesis. Journal of Internet Commerce, 10(3), 208-226. https://doi.org/10.1080/15 332861.2011 .596007

Prastowo, F. A. A. (2020). Pelaksanaan fungsi pokok humas pemerintah pada lembaga pemerintah. Profesi Humas, 5(1), 17-31. https://doi.org/10.24198/prh.v5i1.23721

Savic, M. (2021). From musical.ly to tiktok: social construction of 2020's most downloaded short-video app. International Journal of Communication, 15, 3173-3194.

Song, C., \& Lee, J. (2016). Citizens use of social media in government, perceived transparency, and trust in government. Public Performance and Management Review, 39(2), 430-453. https://doi.org/10 $.1080 / 15309576.2015 .1108798$

Weill, P., Apel, T., Woerner, S. L., \& Banner, J. S. (2019). It pays to have a digitally savvy board. mit sloan management review, cambridge, 60(3), 41-45.

Wright, D. K., \& Hinson, M. D. (2009). An updated look at the 1mpact of social media on public relations practice. Public Relations Journal, 3(2), 1-27. http:// www.instituteforpr.org/iprwp/wp-content/ uploads/Wright_Hinson_PR_Miami.pdf 